\title{
Особливості перебігу раннього післяопераційного періоду у пацієнтів після корекції аневризм лівого шлуночка серця із супутньою ішемічною мітральною недостатністю
}

\author{
Руденко С. А., Лазоришинець В. В., Трембовецька О. М., Руденко А. В., \\ Гогаєва О. К.
}

ДУ «Національний інститут серцево-судинної хірургії імені М. М. Амосова НАМН» (Київ)

\begin{abstract}
Ішемічна хвороба серця (IXC) посідає провідне місце серед актуальних медико-соціальних проблем. Інфаркт міокарда $є$ найбільш грізним ускладненням IXC. У багатьох пацієнтів після виписки зі стаціонару все ж таки залишилися значні порушення функції лівого шлуночка (ЛШ). Одним із загрозливих ускладнень IM є недостатність мітрального клапана ішемічного генезу. Ця патологія зустрічається майже у 20-25\% випадків після гострого інфаркту міокарда (ГІМ) і більш ніж у 50\% пацієнтів, у яких після ГІМ є прояви застійної серцевої недостатності. Наявність мітральної регургітації при IXC негативно впливає на виживання пацієнтів. Смертність протягом першого року становить від 40 до 70\%. В Національному інституті серцево-судинної хірургії імені М. М. Амосова НАМН було прооперовано 693 хворих із приводу аневризми лівого шлуночка. Хворі були розділені на дві групи - з наявністю або з відсутністю мітральної недостатності ішемічного генезу на доопераційному етапі. В першу групу було включено $259(37,4 \%)$ пацієнтів із мітральною недостатністю, в другу групу - 434 (62,6\%) без супутньої мітральної недостатності. Групи пацієнтів були рівнозначні за демографічними показниками і частотою виявлення супутньої патології нервової та судинної систем організму. Більшість досліджуваних хворих групи 1 належали до 3-4 функціонального класу за NYHA (71,8\%), в той час як у другій групі більше третини пацієнтів $(39,2 \%)$ перебували в $1-2$ функціональному класі за NYHA. Інтраопераційні дані штучного кровообігу обох груп не відрізнялися. В післяопераційному періоді у групі з наявною доопераційною мітральною недостатністю час ШВЛ був

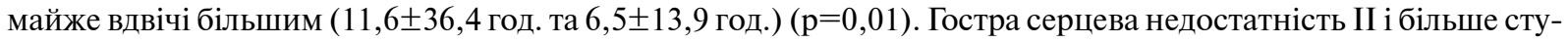
пені виникала в 1,5 рази частіше в групі $1(\mathrm{p}=0,02)$. Гострі порушення мозкового кровообігу в другій групі діагностовані в 2,5\% хворих, а в групі 1 - у 5,0\% пацієнтів (p>0,05). Частота летальних випадків у групі 1 в чотири рази перевищує летальність у групі $2(3,9 \%$ та $0,9 \%$ відповідно) $(\mathrm{p}=0,01)$. Наявність доопераційної мітральної недостатності, навіть якщо вона не потребує корекції, значно погіршує перебіг раннього післяопераційного періоду у пацієнтів після хірургічної корекції аневризми лівого шлуночка і призводить до підвищення частоти виникнення післяопераційних ускладнень та значно збільшує летальність.
\end{abstract}

Ключові слова: ішемічна мітральна недостатність, аневризма лівого шлуночка, ішемічна хвороба серия.

Ішемічна хвороба серця посідає провідне місце серед актуальних медико-соціальних проблем, які стоять перед науковим світом у наш час. Ця хвороба залишається дуже поширеною, можна навіть сказати, що вона набуває епідемічного характеру. Наразі в розвинутих країнах, незважаючи на суттєві досягнення в профілактиці та удосконаленні методів лікування, серед причин загальної смертності населення частка IXC становить близько $30 \%$. Сучасні методи лікування інфаркту міокарда пройшли довгий шлях удосконалення, що сприяло зниженню як госпітальної летальності, так і смертності протягом першого року після виписки з лікувального закладу. Однак показники смертності протягом наступних п'яти років залишаються дуже високими. Диференційний підхід до форм гострого інфаркту міокарда зумовив більш успішне його лікування. Завдяки цьому збільшила- ся кількість хворих, що вижили після декількох (навіть великих) інфарктів міокарда. У багатьох із цих пацієнтів після виписки зі стаціонару все ж таки залишилися значні порушення функції лівого шлуночка (ЛШ). У зв'язку із цим все частіше стало виникати таке ускладнення, як аневризма лівого шлуночка (АЛШ). Аневризма лівого шлуночка доволі поширене ускладнення при трансмуральних IM і зустрічається у 2-38\% хворих [1, 2].

Ще одним грізним ускладненням IM є недостатність мітрального клапана ішемічного генезу. Дана патологія зустрічається майже у $20-25 \%$ випадків після гострого інфаркту міокарда (ГІМ) і більш ніж у $50 \%$ пацієнтів, у яких після ГІМ є прояви застійної серцевої недостатності. Наявність мітральної регургітації при IXC негативно впливає на виживання пацієнтів. Смертність протягом першого року становить від 40 до 


\section{Таблиця 1}

Характеристика пацієнтів по групах

\begin{tabular}{lcccc}
\multicolumn{2}{l}{ Показники } & Група 1 & Група 2 & р \\
\hline \multirow{2}{*}{ Стать } & Чоловіки & $240(92,7 \%)$ & $392(90,3 \%)$ & НД \\
\cline { 2 - 5 } Жінки & $19(7,3 \%)$ & $42(9,7 \%)$ & НД \\
\hline Середній вік & $52,6 \pm 9,1$ & $53,3 \pm 8,9$ & НД \\
\hline Гіпертонічна хвороба & $169(65,2 \%)$ & $282(65,0 \%)$ & НД \\
\hline ГПМК & $13(5,0 \%)$ & $15(3,4 \%)$ & НД
\end{tabular}

70\%. Прогресування регургітації є незалежним предиктором раптової смерті. У пацієнтів із гемодинамічно значущою мітральною недостатністю і коронарною хворобою серця визначається один із найвищих показників летальності після хірургічного лікування від 6 до 22\% [3-5].

Мета роботи - вивчити вплив мітральної недостатності ішемічного генезу на перебіг раннього післяопераційного періоду та результати хірургічного лікування аневризм лівого шлуночка серця.

Матеріали та методи дослідження. В Національному інституті серцево-судинної хірургії імені М. М. Амосова НАМН за останні роки було прооперовано 693 хворих із приводу аневризми лівого шлуночка. Розподіл пацієнтів за статтю при наявності аневризми лівого шлуночка відповідає загальному розподілу пацієнтів при IХС. Хворих чоловічої статі було 632 (91,2\%), жіночої - 61 (8,8\%). Середній вік пацієнтів становив $53,8 \pm 9,0$ років. Супутня мітральна недостатність ішемічного генезу була виявлена у 259 пацієнтів $(37,4 \%)$.

Хворі були розділені на дві групи залежно від наявності або відсутності мітральної недостатності ішемічного генезу на доопераційному етапі. В першу групу було включено $259(37,4 \%)$ пацієнтів із мітральною недостатністю, а в другу групу $-434(62,6 \%)$ без супутньої мітральної недостатності.

Згідно з даними табл. 1, групи пацієнтів були рівнозначними за демографічними показниками і частотою виявлення супутньої патології нервової та судинної систем організму. Так, у першій групі середній вік складав $52,6 \pm 9,1$ років, а в другій $-53,3 \pm 8,9$ років. Гіпертонічна хвороба ускладнювала перебіг хвороби однаково часто в обох групах.

\section{Таблиця 3}

Дані ехокардіографічного обстеження

\begin{tabular}{lccc} 
Показник & $\begin{array}{c}\text { Група 1 } \\
(\mathbf{n = 2 5 9 )}\end{array}$ & $\begin{array}{c}\text { Група 2 } \\
(\mathbf{n = 4 3 4 )}\end{array}$ & $\mathbf{P}$ \\
\hline КДО (мл) & $202,7 \pm 55,2$ & $177,9 \pm 51,2$ & $<0,01$ \\
\hline КСО (Мл) & $112,0 \pm 43,7$ & $98,9 \pm 41,8$ & $>0,05$ \\
\hline УО (мл) & $88,8 \pm 23,4$ & $79,1 \pm 19,1$ & $<0,01$ \\
\hline ФВ (\%) & $43,1 \pm 9,1$ & $44,1 \pm 9,9$ & $>0,05$
\end{tabular}

\section{Таблиця 2}

Розподіл пацієнтів за NYHA

\begin{tabular}{lccc} 
Функціональний клас & $\begin{array}{c}\text { Група 1 } \\
\text { (n=259) }\end{array}$ & $\begin{array}{c}\text { Група 2 } \\
\text { (n=434) }\end{array}$ & p \\
\hline NYHA 1 ф. к. & $9(3,5 \%)$ & $33(7,6 \%)$ & $>0,05$ \\
\hline NYHA 2 ф.к. & $64(24,7 \%)$ & $137(31,6 \%)$ & $\approx 0,05$ \\
\hline NYHA 3 ф. к. & $174(67,2 \%)$ & $254(58,5 \%)$ & $\approx 0,05$ \\
\hline NYHA 4 ф. к. & $12(4,6 \%)$ & $10(2,3 \%)$ & $>0,05$
\end{tabular}

Більшість досліджуваних хворих $(71,8 \%)$ групи 1 належали до 3-4 функціонального класу за NYHA, в той час як у другій групі більше третини $(39,2 \%)$ пацієнтів були в 1-2 функціональному класі за NYHA.

Після першого інфаркту міокарда за хірургічною допомогою звернулося 52,5\% (136) хворих першої групи та $60,1 \%$ (261) - другої групи. Ще 44 (6,3\%) пацієнтів з обох груп заперечували наявність інфаркту міокарда в анамнезі.

Середній показник доопераційної фракції викиду суттєво не відрізнявся в обох групах $(43,1 \pm 9,1 \%$ та $44,1 \pm 9,9 \%)(\mathrm{p}>0,05)$.

У першій групі хворих КДО був більшим, ніж у другій групі $(202,7 \pm 55,2$ мл та $177,9 \pm 51,2$ мл відповідно) $(\mathrm{p}<0,01)$, що якраз було зумовлено наявністю ішемічної мітральної недостатності.

Результати та обговорення. В Інституті ми використовуємо диференційований підхід до вибору методики пластики ЛШ. Основним показником, за яким вирішували, за якою методикою проводити пластику ЛШ, була локалізація АЛШ.

Лінійна пластика використовувалася при передньо-боковій, передньо-верхівковій локалізації АЛШ та при аневризмі верхівки ЛШ. Якщо патологічний процес поширюється на МШП, то в такому випадку неможливо повністю усунути АЛШ і одночасно зберегти правильну форму і адекватний об'єм ЛШ. В такому випадку використовувалася ендовентрикулопластика, яка дозволяла виключити уражену МШП з кровообігу. Ендовентрикулопластику виконували при передньо-перегородково-верхівкових АЛШ. За умови ураження ще і задньої стінки ЛШ сама ендовентрикулопластика виявилася неефективною. Тому виникала потреба доповнити ії внутрішньою циркулярною латкою (ЕVCРP).

Інтраопераційні дані штучного кровообігу обох груп майже не відрізняються. Це зумовлено тим, що ступінь вираженості мітральної недостатності не потребував корекції і основний етап операції в групах не відрізнявся.

Згідно з даними табл. 4, у досліджуваних групах не було різниці в частоті ураження правої коронарної артерії $(47,5 \%$ проти 47,2\%) (p>0,05), дещо частіше шунтувалася огинаюча гілка в другій групі $(47,9 \%$ 


\section{Таблиця 4}

Характеристики інтра- та післяопераційного періоду

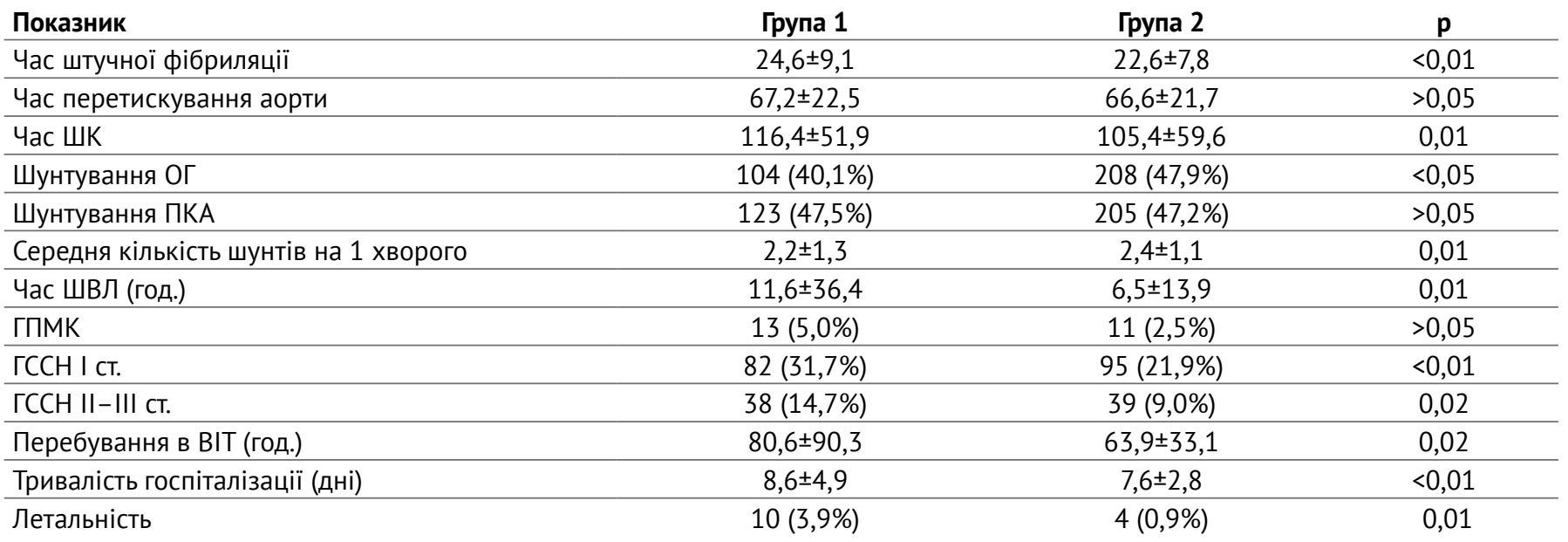

проти 40,1\%) (p<0,05). В кількості дистальних анастомозів також не помічено значущої різниці між групами. Але звертає на себе увагу час штучної вентиляції легень у післяопераційному періоді. В групі з наявною доопераційною мітральною недостатністю час ШВЛ майже вдвічі більший $(11,6 \pm 36,4$ год. та $6,5 \pm 13,9$ год.) $(\mathrm{p}=0,01)$. Хворі першої групи більше часу проводили у відділенні інтенсивної терапії $(80,6 \pm 90,3$ год. проти $63,9 \pm 33,1$ год.) $(\mathrm{p}=0,02)$. Гостра серцева недостатність II і більше ступеня виникала в 1,5 рази частіше у групі $1(p=0,02)$. Гострі порушення мозкового кровообігу в другій групі виникали в $2,5 \%$ хворих, а в групі $1-$ у 5,0\% пацієнтів, але ця різниця виявилася недостовірною $(\mathrm{p}>0,05)$. Частота летальних випадків також більша в групі 1: вона в чотири рази перевищує летальність у групі 2 (3,9\% та $0,9 \%$ відповідно) $(\mathrm{p}=0,01)$. Завдяки розробленому в Інституті диференційованому підходу до пластики аневризм лівого шлуночка результати хірургічної корекції даної патології краші, ніж в інших провідних центрах світу [6].

Висновки. Наявність доопераційної мітральної недостатності, навіть якщо вона не потребує корекції, значно погіршує перебіг раннього післяопераційного періоду у пацієнтів після хірургічної корекції аневризми лівого шлуночка і призводить до підвищення частоти виникнення післяопераційних ускладнень та значно збільшує летальність.

\section{Література}

1. Лазоришинець В.В. До відкриття VII Польсько-українського кардіохірургічного форуму «Прогресивні досягнення в кардіохірургії - обмін досвідом». Вісник серцево-судинної хірургії. - К., 2017. - № 1 (27). C. $8-9$.

2. Valuckiene Z, Budrys P, Jurkevicius R. Predicting ischemic mitral regurgitation in patients with acute ST-elevation myocardial infarction: Does time to reperfusion really matter and what is the role of collateral circulation? Int $\mathbf{J}$ Cardiol 2015;203:667-671.

3. Petrie MC, Jhund PS, She L, et al. STICH Trial Investigators. Ten-year outcomes after coronary artery bypass grafting according to age in patients with heart failure and left ventricular systolic dysfunction: an analysis of the extended follow-up of the STICH trial (surgical treatment for ischemic heart failure). Circulation 2016; 134:1314-1324.

4. Jeganathan R, Maganti M, Badiwala M, Rao V.Concomitant mitral valve surgery in those patients undergoing surgical ventricular reconstruction for ischaemic cardiomyopathy. Eur J Cardiothorac Surg 2013; 43: 1000-1005.

5. Onishi T, Saha SK, Delgado-Montero A, et al: Global longitudinal strain and global circumferential strain by speckle-tracking echocardiography and feature-tracking cardiac magnetic resonance imaging: Comparison with left ventricular ejection fraction. J Am Soc Echocardiogr 2015;28:587-596.

6. Salah E. Altarabsheh, Salil V. Deo, Shannon M. Dunlay, Patricia J. Erwin, Yagthan M. Obeidat, Suparna Navale et al. Meta-Analysis of Usefulness of Concomitant Mitral Valve Repair or Replacement for Moderate Ischemic Mitral Regurgitation With Coronary Artery Bypass Grafting. Am J Cardiol 2017;119:734-741. 


\title{
Peculiarities of the course of the early postoperative period in patients after correction of left ventricular aneurysm with concomitant ischemic mitral insufficiency
}

\author{
Rudenko S., Lazoryshynetz V., Trembovetskaya O., Rudenko A., Gogaeva O. \\ National M. M. Amosov Institute of Cardiovascular Surgery National Academy of Medical Sciences of Ukraine (Kyiv)
}

Ischemic heart disease (IHD) is a leading place among the topical medical and social problems. Myocardial infarction (MI) is the most formidable complication of IHD. Many of these patients, after discharge from the hospital, still had significant violations of the function of the left ventricle (LV). One of the terrible complications of MI is the inadequacy of mitral valve ischemic genesis. This pathology occurs in almost $20-25 \%$ of cases after acute myocardial infarction (AMI) and more than $50 \%$ of patients who have symptoms of congestive heart failure after AMI. The presence of mitral regurgitation in IHD negatively affects the survival of patients. Mortality during the first year is from 40 to $70 \%$. At the National Institute of Cardiovascular Surgery operated 693 patients with a left ventricular aneurysm. The patients were divided into two groups the presence or absence of mitral insufficiency of the ischemic genesis at the preoperative stage. The first group included 259 (37.4\%) patients with mitral insufficiency, and the second group - 434 (62.6\%) without concomitant mitral insufficiency. Groups of patients were equivalent to demographic indicators and the frequency of the detection of concomitant pathology of the nervous and vascular systems of the body. Most of the patients under study group 1 related to NYHA class 3-4 (71.8\%), while in the second group, more than a third of patients $(39.2 \%)$ were in the NYHA class 1-2 functional class. The intraoperative data of the artificial blood circulation of the two groups did not different. In the postoperative period, in the group with preoperative mitral insufficiency, the time of mechanical ventilation is almost twice as high $(11.6 \pm 36.4 \mathrm{~h}$ and $6.5 \pm 13.9 \mathrm{~h})(\mathrm{p}=0.01)$. Acute heart failure II and more degrees occurred in 1.5 times more often in group №1 ( $\mathrm{p}=0.02)$. Acute cerebrovascular accidents in the second group are diagnosed in $2.5 \%$ of patients, and in group $1-$ in $5,0 \%$ of patients $(p>0,05)$. The mortality in group 1 increases four times the death rate in group $2(3.9 \%$ and $0.9 \%$, respectively) $(p=0.01)$. The presence of preoperative mitral insufficiency, even if it does not require correction, significantly worsens the course of the early postoperative period of patients after surgical correction of the left ventricular aneurysm and leads to an increase in the incidence of postoperative complications and significantly increases mortality.

Key words: ischemic mitral insufficiency, left ventricular aneurysm, ischemic heart disease. 